\title{
Women and Tourism Are the Most Important Challenges They Face in Jordan
}

\author{
Mohammad Nayef Alsarayreh ${ }^{1}$ \\ ${ }^{1}$ Al-Balqa Applied University, Jordan \\ Correspondence: Mohammad Nayef Alsarayreh, Al-Balqa’ Applied University, Jordan.
}

Received: July 19, 2018

doi:10.5430/ijba.v9n6p39
Accepted: October 3, 2018

Online Published: October 11, 2018

URL: https://doi.org/10.5430/ijba.v9n6p39

\begin{abstract}
This study aims at identifying the challenges faced by Jordanian women working in the tourism and hotel sector. This study seeks to answer the following: What is the degree of challenges faced by Jordanian women working in the tourism and hotel sector?

This study belongs to the analytical exploratory studies and follows the method of data collection and analysis to reach results. 200 questionnaires were distributed, of which 180 were returned and 10 were excluded. A questionnaire was based on 170 employees who were able to obtain their data.

The study found that the greatest Obstacles faced by working women were family difficulties and social difficulties. The study recommended changing the family's view of women and accepting them as employees.
\end{abstract}

Keywords: women, tourism, challenge, hotel

\section{Introduction}

It is necessary to change the dark outlook that is directed towards women during their work in any sector, where the culture of defect is the most prominent obstacles facing the work of women in the tourism sector, and it is no secret to us that women can play a prominent role in the field of tourism development as an important element In the activation and support of tourism and revitalization locally, in addition to being the one who is often the first and final decision in the practice of tourism activity at the family level, and women being part of the community work in the field of tourism will achieve great gains for tourism in terms of planning the community, Especially the tourism of families and families of the most important tourist activities in the Arab world, and therefore see specialists in this area that raise the participation of women in the tourism sector will help to identify the needs of the family of tourism programs and events, in addition to making the tourism industry attractive and increase the number of women to work in it, And tourism policymakers in any country should be well aware of this.

The educational skills have led to an increase in the number of females working in high-paying jobs in the country, but the percentage of women's participation in the tourism and hotel sector in Jordan has not reached more than 5\%, which is the total number of workers in the tourism sector, where males constitute $95 \%$ of the total workforce, On the other hand, there is a clear difference between the ratio of females to males enrolled in university tourism education, where the percentage of females is not more than $28 \%$ of the total enrolled in tourism and hotel specialization at the university level. At the secondary level, the female enrollment rate in the tourism and tourism sector is estimated at zero, Suggesting There is a clear imbalance in the structure of guidance and educational guidance, especially in light of the need of Jordan to 25 thousand job opportunities during the next three years in light of the continued expansion of tourism investments, so the Jordanian government to develop a plan of action to increase the enrollment of females in tourism and hotel education.

\section{Previous Studies}

Zerouq, Adlan, (2016) Problems and obstacles to the work of women journalists and journalists in the Algerian private television channels: a field survey of a sample of women journalists

This research focuses on the obstacles faced by women journalists and media professionals who are not working in private TV channels such as: Al Shorouq, Numidia News, tv, sports goalscorer ... This is done by conducting a field survey using the survey method with the form tool (100) form. In this study we aim to reach the most important 
obstacles and obstacles to stand in the face of women journalists and media outlets in the Algerian private channels. Therefore, we can raise the main issue of our research as follows: What are the most important obstacles and problems facing women journalists and media in the private television channels in Algeria?

Abdel Wahid, Mo'men Khalaf (2015), Women's Obstacles to Leading Behavior in Palestinian Ministries in the Gaza Strip,

This study aimed at identifying the obstacles facing female employees and preventing them from exercising the leadership role in the Palestinian ministries in the Gaza Strip. The researcher used the descriptive approach. The study population may be from all the employees in the ministries and their number is 32165 employees. (467) employees and employees, 435 of whom responded (93.15\%) of the sample of the actual study. In order to achieve the objectives of the study, the researcher designed a questionnaire consisting of (38) paragraphs divided into four areas namely obstacles (social, administrative, personal, legal), and the researcher using SPSS statistical program. The study found the following main results: Social, administrative, personal, and legal obstacles have a direct impact on the level of significance of 0.05 on female employees in the Palestinian ministries in the Gaza Strip. There are no statistically significant differences at the level of significance of 0.05 in the views of the sample members in the average of the estimates of the employees - the obstacles that prevent the woman from exercising the leadership role attributed to the variable (gender-age-specialization, marital status, number of family members, years of experience, Living.

Qawarah, Migration (2015) Obstacles of Women Benefiting from Microcredit"

The study aimed to answer the main question: What are the obstacles of the work of women benefiting from micro-loan in the city of Ouargla? To answer this question, the following assumptions were made: The value of the loan hinders the work of the woman benefiting from the micro-loan in the city of Ouargla. The family hinders the work of women benefiting from the micro-loan in the city of Ouargla. In response to the previous hypotheses, we have relied on a set of methodological procedures in the descriptive approach, using data collection tools such as questionnaire and interview, as well as data analysis methods. This study was applied to a sample of 25 women beneficiaries of the microcredit project in Ouargla city, which was deliberately selected. The results of the study revealed that there are obstacles to the functioning of women beneficiaries of the microcredit, most notably the value of the loan considered for her or the difficulty of dealing with technology, but the family was an important factor in the women's project, as it was supporting either materially or morally, And full satisfaction with income, despite the obstacles encountered with regard to the value of the loan.

Hassan Al-Yaqoubi (2012) Obstacles to Women's Work in the Higher Administrative Leadership of Iraqi Universities (Karbala University Model) The present research is concerned with a scientific study aimed at verifying many difficulties that hinder the advancement of women to senior management positions in Iraqi universities. Obstacles to Iraqi women's access to higher university leadership.

\section{The Study Problem}

The difficulties and challenges faced by Arab women working in general and the tourism sector and hotels in particular, and the problem of the study was identified by the following question:

What are the difficulties faced by Jordanian women working in the tourism sector and hotel from the perspective of female employees.

\section{The Importance of Studying}

The importance of this study stems from the importance of tourism itself, which is of great importance as economic activity and human phenomenon in different countries of the world, besides its economic impact on the state and society.

Tourism and hotel work is the key to pushing females to a better level in the labor market. However, Jordanian women, despite the barriers to social inheritance, have begun to participate in the tourism workforce and are on the way to becoming an active participant in tourism development.

\section{Objectives of the Study}

This study aims to identify the difficulties faced by Jordanian women working in the tourism and hotel sector from the point of view of female employees and to identify the social, family, administrative and legal difficulties faced by Jordanian women in the tourism and hotel sector. 


\section{Type of Study, Methodology, Sample and Society of the Study}

This study belongs to the analytical exploratory studies and adopts the method of collecting and analyzing data to reach the results. The study is conducted on female employees in the tourism and hotel sector, and 200 questionnaires were distributed, 180 of which were returned and 10 were excluded. The questionnaire was based on a survey of 170 employees who were able to obtain their data. They worked in tourist and hotel establishments. The data were collected through the questionnaire and they represent the research community and the sample of the study.

\section{Hypotheses}

1. There are no statistically significant differences in the difficulties faced by Jordanian women working in the tourism and hotel sector due to: gender variable, age, variable social status, number of children and scientific qualification.

2. There are family difficulties of statistical significance facing women working in the tourism and hotel sector.

3. There are social difficulties of statistical significance facing women working in the tourism and hotel sector.

\section{Stability of Instrument}

The stability of instrument was tested by Chronbach Alpha coefficient where:

1. Alpha value for family difficulties was 0.78

2. Alpha value for social difficulties was 0.90

3. Alpha value for all items was 0.68

All these values were $>0.8$ which means stability of instrument as shown in table 1

Table 1. Results of chronbach alpha coefficial test for study dimensions

\begin{tabular}{ll}
\hline Alpha Value & Dimension \\
\hline $\mathbf{0 . 7 8}$ & Family difficulties \\
$\mathbf{0 . 9 0}$ & Social difficulties \\
$\mathbf{0 . 9 1}$ & All items \\
\hline
\end{tabular}

Fist: Description of personal and job factors of Respondents

Table 2 present, the description of personal and job factors of sample respondents as follows:

- Age segment:

The data showed that $45.1 \%$ of the sample was at the age of $40-49$ years segment, while $50 \%$ of the samples were at the segment of 29-39 years, besides that $20.2 \%$ of the sample stayed in the segment of $18-28$ years and $12.5 \%$ were 51 years and more.

$\circ \quad$ Years of experience

The table shows that $44.3 \%$ of the sample have experience of six years or more; $33.1 \%$ have experience between 1-2 years; wile $60.1 \%$ of the sample have experience of 3-6 years and $20.5 \%$ have experience one year or less

$\circ$ Average monthly income

The table shows that $48.3 \%$ of the sample obtained monthly income between $351-550 \mathrm{JD} ; 30.5 \%$ obtained income between 550-750, while $40.6 \%$ of the sample obtained monthly income more than 751JD and 50.4\% obtained income between 250-350JD.

○ Marital statues

$80 \%$ of the samples were Single.

- Education level

55\% of the ample held Bachelor degree; 35\% held Diploma; $15 \%$ held Master degree; $30 \%$ held secondary school certificate and 5\% held $\mathrm{PhD}$

○ Number of children 
$45 \%$ of the ample have $1-3$ children; $54 \%$ have no children while $359 \%$ have 4 children or more.

Table 2. Frequencies and percentages for the personal variables of the respondents

\begin{tabular}{llll}
\hline Factor & Elements & Freq & $\%$ \\
\hline Age Segment & $18-28$ & 60 & 20.2 \\
& $29-39$ & 17 & 50.2 \\
& $40-49$ & 70 & 45.1 \\
Years of Experience & $50+$ & 50 & 17.3 \\
& 8 or less & 20 & 9.5 \\
& $1-2$ & 100 & 60.1 \\
Monthly salary (income & $3-6$ & 30 & 20.5 \\
JD) & $7+$ & 140 & 70.1 \\
& $250-350$ & 40 & 15 \\
Martial Status & $351-550$ & 80 & 30.5 \\
\multirow{5}{*}{ Educational Level } & $551-750$. & 60 & 40.6 \\
& $751+$ & 70 & 50.4 \\
& Married & 60 & 20 \\
& Single & 110 & 80 \\
& Secondary & 50 & 30 \\
No. of Children & Diploma & 40 & 35 \\
& Bachelor & 80 & 55 \\
& Master & 20 & 15 \\
& PhD & 10 & 5 \\
& No children & 80 & 54 \\
& $1-3$ & 40 & 45 \\
& $4+$ & 50 & 25 \\
\hline
\end{tabular}

\section{Test of the Hypotheses}

H1: There are no statistically significant differences among difficulties that encounter the women in tourism sector; attributed to age, number of children, education level, and marital status.

\subsection{Age}

Table 3 shows that, except the aspect of social difficulties, all aspects obtained significance levels $>0.00$ which means no statically significant difference among these difficulties. For the social difficulties the level of observed significance was $0.00<0.05$ which means that there were differences attributed to age in the social difficulties aspect. To determine the sources of differences a Tukey test was performed as shown in Table 4. There were two statistical differences among (29-39) and both (40-49) and 50+ segments to the favor of the latte both segments. It means that those of 31-40 years of age felt social difficulties more than other to segments.

Table 3. Result of ANOVA test for the differences among age, education level, number of children and martial status

\begin{tabular}{lllll}
\hline \multicolumn{1}{c}{ Dimension } & $\begin{array}{l}\text { Sig. level att. } \\
\text { To Age }\end{array}$ & $\begin{array}{l}\text { Sig. level att To } \\
\text { No. children }\end{array}$ & $\begin{array}{l}\text { Sig. level att } \\
\text { To Education }\end{array}$ & $\begin{array}{l}\text { Sig. level att } \\
\text { To Martial st }\end{array}$ \\
\hline Family difficulties & 0.18 & 0.60 & 0.30 & 0.56 \\
Social difficulties & 0.05 & 0.40 & 0.29 & 0.20 \\
\hline
\end{tabular}

Table 4. Results of Tukey test for sources of differences in social difficulties attributed to age

\begin{tabular}{lllll}
\hline Age & $18-28$ & $29-39$ & $40-49$ & $50+$ \\
\hline $20-30$ & $\mathrm{X}$ & 0.08 & $\mathrm{X}$ & $\mathrm{X}$ \\
$31-40$ & 0.30 & $\mathrm{X}$ & 0.05 & $\mathrm{X}$ \\
$41-50$ & -0.05 & $*_{-}-0.40$ & $\mathrm{X}$ & $\mathrm{X}$ \\
$51+$ & -0.03 & $*_{-} 0.64$ & -0.07 & $\mathrm{X}$ \\
\hline
\end{tabular}




\subsection{Number of Children}

Table 3 shows that all levels of significance were $>0.05$, which means no statically significant differences among the difficulties attributed to the number of children.

\subsection{Level of Education}

table 3 shows that, except the administrative difficulties, all dimensions obtained significance level $>0.05$ which means that there were no statistically significant differences among the difficulties encounter women in tourism sector attributed to educational level. For the administrative dimension the significant level was $<0.05$, where table 5 shows that there were three statistical differences.

1 one difference between secondary school and diploma to the favor of secondary.

2+3. Two differences between diploma and both Master and PhD holders, to the favor of both latter's.

Table 5. Tukey test result for the sources of differences in administrative difficulties attributed to educational level

\begin{tabular}{llllll}
\hline Ed. level & $\begin{array}{l}\text { Secondary } \\
\text { school }\end{array}$ & Diploma & Bachelor & Master & $\mathrm{PhD}$ \\
\hline Secondary school & $\mathrm{X}$ & $\mathrm{X}$ & 0.06 & 0.05 & $\mathrm{X}$ \\
Diploma & $* 0.50$ & $\mathrm{X}$ & $\mathrm{X}$ & $\mathrm{X}$ & $\mathrm{X}$ \\
Bachelor & 0.14 & -0.20 & $\mathrm{X}$ & $\mathrm{X}$ & $\mathrm{X}$ \\
Master & 0.06 & $*_{-} 0.54$ & -0.09 & $\mathrm{X}$ & $\mathrm{X}$ \\
PhD & -0.1 & $*_{-0.30}$ & -0.40 & -0.07 & $\mathrm{X}$ \\
\hline
\end{tabular}

\subsection{Marital Status}

Table 3 shows that all levels of significance were $>0.05$ which means no differences attributed to marital status.

$\mathrm{H} 2$ : There are family difficulties with statistical significance that encounter women in tourism sector.

Table 6 shows that arithmetic means for items were $>3.5$ and significance levels $<0.05$. This means that these items were statistically significant, so these difficulties were actually existed. Item 4 got the first rank with a mean of 4.03, which means that the most difficult obstacle was Difficult to accept husband's women's work in tourism out of jealousy. The second rank was obtained by item 3 with a mean of 4.02 , where such item was the husband can not cope with the repeated absence of the wife at work and private tourism in exceptional circumstances. The item 2 got a mean of 1 where it was that women working in tourism negatively affects the stability of family.

All items combined obtained a mean of 4.06 and significance level of zero, which mans that such items were statistically significant. Therefore the second hypothesis was acceptable.

Table 6. Arithmetic mean, std. dev., $\mathrm{t}$ value, and significance level of family difficulties

\begin{tabular}{llllll}
\hline Item No & Item Content & Arith mean & Std dev & T value & Sig level \\
\hline 1 & $\begin{array}{l}\text { Difficult to accept husband's women's } \\
\text { work in tourism out of jealousy }\end{array}$ & 4.08 & 0.50 & 15.60 & 0.00 \\
2 & $\begin{array}{l}\text { The supervision of women raising children } \\
\text { on her way to prevent the tourist sector }\end{array}$ & 4.06 & 0.60 & 14.65 & 0.00 \\
3 & $\begin{array}{l}\text { The woman's guardian opposed to } \\
\text { women's work in tourism }\end{array}$ & 4.02 & 0.70 & 11.694 & 0.00 \\
$\begin{array}{l}\text { The women who work have children are } \\
\text { superior in the study }\end{array}$ & 4.03 & 0.75 & 17.65 & 0.00 \\
All items & 4.06 & 0.76 & 15.69 & 0.00 \\
\hline
\end{tabular}

H3: there are social difficulties of statistical significance encounter women working in tourism and hoteliery sector.

Table 7 shows that all means of social difficulties items were $>3.5$ and significance levels $<0.05$. This means that these items were statistically significant, so these difficulties were actually existed. Item 9 , which measured the Customs and traditions of an obstacle for women to work in the tourist, obtained the first rank with a mean of 3.16. 
Item 7, which measured the Mixing a barrier to women's employment in tourism because it is socially unacceptable, obtained the second rank with a mean of 3.15. Item 5 obtained the last rank with a mean of 3.18.

All items combined obtained a mean of 3.09 and observed significance level of zero. Therefore the third hypothesis was acceptable.

Table 7. Arithmetic mean, std. dev., $t$ value, and significance level of social difficulties

\begin{tabular}{|c|c|c|c|c|c|}
\hline Item No & Item Content & Arith mean & Std dev & T value & Sig level \\
\hline 5 & $\begin{array}{l}\text { Adherence to religious teachings in the society } \\
\text { prevents women from working in tourism }\end{array}$ & 3.15 & 0.60 & 15.20 & 0.00 \\
\hline 6 & $\begin{array}{l}\text { Not convinced relatives to work for women } \\
\text { tourist }\end{array}$ & 3.18 & 0.70 & 11.35 & 0.00 \\
\hline 7 & $\begin{array}{l}\text { Customs and traditions of an obstacle for women } \\
\text { to work in the tourist }\end{array}$ & 3.16 & 0.80 & 13.25 & 0.00 \\
\hline 8 & $\begin{array}{l}\text { The existence of false convictions in the } \\
\text { community about the nature of work in the } \\
\text { tourism sector }\end{array}$ & 3.09 & 0.77 & 11.25 & 0.00 \\
\hline \multirow[t]{2}{*}{9} & $\begin{array}{l}\text { Community's rejection of the women left in the } \\
\text { later times }\end{array}$ & 3.09 & 0.55 & 10.00 & 0.00 \\
\hline & All items & 3.15 & 0.65 & 12.50 & 0.00 \\
\hline
\end{tabular}

\section{Results}

1). There are family difficulties facing women working in the tourism sector and hotel.

2). The view of the family in general as a housewife is better than being one of the most difficult.

3). The least difficulty was the difficulty of doing homework because of the length of working hours.

4). There are social difficulties facing women working in the tourism sector and hotel.

5). The most difficult difficulties were the imposition by society of certain areas of work for women.

6). The view of the inferiority of women as if they were inferior to men.

7). The greatest difficulties faced by working women were family difficulties and social difficulties.

\section{Recommendations}

1). To overcome the family difficulties facing the working time, especially work to change the family's view of women and accept them as an employee.

2). Increase attention to the issue of women's work in the tourism sector, and in particular to ensure justice in promotions, incentives and treatment.

3). The need to train women to work in the tourism sector to think and renewal more attention.

4). Conduct similar studies to investigate the difficulties faced by women working in the tourism sector, using the latest percentages and numbers.

\section{References}

Abdel, W., \& Mo'men, K. (2015). Obstacles to the exercise of leadership behavior in the Palestinian ministries in the Gaza Strip. Palestine University Research and Studies Journal, 5(2), 377-422.

Al-Rasheed, A., et al. (2001). Women's Attitudes Toward the Obstacles of their Progress in Jordanian Business Organizations. Journal of Administrative Sciences, 28(1), 29-30. University of Jordan, Amman, Jordan.

Alturky, T., et al. (2010). The Change of Values in the Arab Family. The Arab Future, 39(200).

Badria bint Mohammed bin Masoud al-Otaibi. (2011). Family and social effects of work (outside the home)-educated and married woman with children-Master Thesis. Imam Muhammad bin Masood Islamic University, Faculty of Social Sciences.

Farhat, N. (2012). Women's Work and its Impact on Family Relations. Journal of the Academy for Social and Human Studies, (8). 
Hassan, Y. (2012). Obstacles to the work of women in the senior administrative leadership of Iraqi universities (University of Karbala model). Journal of University of Babylon, 20(2), 327-348.

Kawareh, M. (2015). Obstacles of Women Benefiting from Microcredit. University of Qasidi Marbah and Argla, Faculty of Humanities and Social Sciences, Master Thesis, Algeria.

Marai, K. (2001). Obstacles to the Career Advancement of Jordanian Women Employed in Business Organizations in Sahab and Al Hassan Industrial Cities: A Field Study (Unpublished Master Thesis). Yarmouk University, Jordan.

Zerouq, A. (2016). Problems and obstacles to the work of women journalists and media in the Algerian private television channels: A field survey of a sample of female journalists of the channels (Sunrise and Atmosphere). Women and Media Conference and the Challenges of Communication Revolution. Algeria.

Zubaida, B.A. (1986). Following the work of the mother's wife in the construction of the Algerian family. Master of Sociology, Institute of Sociology, University of Algiers. 